\title{
The utilization of organic waste into fermented goat fodder in Tanjung Rejo village, Deli Serdang regency
}

\author{
Mayang Sari Yeanny ${ }^{1 *}$, Yurnaliza ${ }^{1}$, Saleha Hannum ${ }^{1}$ \\ ${ }^{1}$ Department of Biology, Faculty of Mathematics and Natural Sciences, Universitas Sumatera \\ Utara, Medan, Indonesia \\ *Email: mayang@usu.ac.id
}

\begin{abstract}
Community service activities with the title of The Utilization of Organic Waste into Fermented Goat Fodder in Tanjung Rejo Village, Deli Serdang Regency will be held in May - November 2019.The purpose of this community service is to utilize organic waste into fermented goat fodder in Tanjung Rejo village.Organic waste such as straw, banana tree and others can be converted into fermented goat fodder which is economical, nutritious and environmentally friendly. The specific target of this community service is that the fermented goat fodder produced can be stored for a long time with good quality. The method used is a combination of counselling, training, hands-on practice and work evaluation.The procedures of making fermented goat fodder are as follows; (1) Chop straw or banana tree using a chopper machine, this stage serves to make the fermentation process easier. (2) Prepare the place of manufacture, can use tarpaulins, large plastic or large barrels (3). Dissolve sugar or sugar cane with water plus SOC-HCS probiotic solution. (4) Enter the straw, husk and bran at the place of preparation that has been prepared previously. (5) Flush all materials that have been arranged evenly in the place of manufacture with a solution of sugar and SOC-HCS that had been dissolved with water. (6) Mix all ingredients evenly. (7) After everything has been stirred evenly, then cover the place of manufacture with a tarp or with anything, make sure to be airtight. (8) Wait for 1 - 14 days. The fermented fodder that you have made from straw will be ready or if the fermentation feed is made using a banana tree, it can be faster.All products produced can be used for their own needs or sold according to the needs of the people of Tanjung Rejo village, especially the Tanjung Rejo goat breeders group.
\end{abstract}

Keyword: Organic Waste, Fermented Goat Fodder, Tanjung Rejo Village

\section{INTRODUCTION}

Data from the University of Sumatera Utara - Directorate General of Animal Husbandry and Animal Health (2017) showed that the population of goats in Sumatera Utara in 2017 amounted to 920,620 heads, goat slaughtered amounted to 25,807 and goat meat production amounted to 157,687 tons. High demand for goat meat is one of the promising and profitable business alternatives that can be relied upon as a source of family income.

Most people in the village of Tanjung Rejo work as breeders. Breeders raise chickens, ducks, goats and cattle. Breeders in the village of Tanjung Rejo also gained a small amount of knowledge about breeding. Livestock products can only meet their daily needs because the production process of raising livestock requires a large cost, especially feed, hence breeders borrow money first to moneylenders for the production process.

In Tanjung Rejo village, breeders, especially goat breeders, always have difficulty in preparing feed for the livestock, especially in the dry season, while organic waste such as straw, and the banana stem is not used, most of them leave it. Only a small portion uses it as feed and this feed must be used up as soon as possible so as not to cause odour.Besides, organic waste is very annoying if thrown away and just leave it like trash. With the utilization of organic waste as fermented animal feed for fattening is economical, high nutritional value and environmentally friendly.

Fermented feed is economically very useful because the composition is mixed in the feed and can be stored for a long time. Usually, breeders mix their rations for goats, but fermented feed for fattening is already equipped with quality goat fodder. Fermented food is also environmentally 
friendly because it utilizes organic waste to its full potential and does not become garbage while preserving the environment.

Feed management is very dependent on the feed given to livestock. Nutrient content contained in feed must be really considered to get the desired production results (Eka et al, 2019).An important factor influencing the Increase Body Weight (IBW) is feed consumption, the higher the amount of feed consumed by livestock, the higher the rate of growth.IBW can occur if livestock are able to convert feed substances that are absorbed into livestock products such as fat and meat after their basic needs are met (Alim, 2014)

Based on this situation, the community service team carried out community service in Tanjung Rejo village, Percut Sei Tuan Subdistrict, Deli Serdang Regency with the village community, especially the goat breeders, this community service was done to improve human resources (HR) by utilizing organic waste into fermented goat feed in Tanjung Rejo village.

\section{METHODS}

The method used in this activity was a combination of counselling, training, hands-on practice and work evaluation. This activity was supported by the village chief and his officials will play a role in helping this implementation by giving permission and contacting the community groups of goat breeders. The benefits obtained will increase the knowledge of human resources in terms of the utilization of organic waste as fermented feed.

Breeder groups act as objects of the organic waste utilization to goat fermentation feed. The benefits obtained by breeders will increase knowledge, save the environment from waste and will ultimately help the economy and will improve their living standards.

In this community service group of breeders can cooperate in making fermented feed for fattening goats, because breeders need these products. In making feed is very easy, practical, economical, and inexpensive, only requires a little time and anyone can do it.Besides, the ingredients are available in the community and a very appropriate alternative to overcome the scarcity and rising of animal feed. Working methods of goat fodder can be seen as follows:

\subsection{Data Collecting Methods}

The data collection method was done by:

1. Interview: By taking primary data through interviewing some local community.

2. Field Observation: Field observations were carried out with the community.

3. Library Research was conducted to complete the information obtained regarding the manufacture and application of fermented feed hence it is made optimally.

\subsection{Approach Method}

This method was carried out by way of counselling, training, and direct practice to the surrounding community on how to make and implement the method of making goat fermentation feed.It is intended that the surrounding community can reduce the expenditure of excess funds to provide animal feed, as this animal feed is healthier and has a high nutritional value and is environmentally friendly.

\subsection{Implementation Methods}

Tools and ingredients for making goat fermented feed:

1. Chopping tool or you can use a machete etc.

2. Tarpaulin, large plastic or large cask

3. Straw or banana stem

4. Drops of sugar or sugar cane

5. Probiotic supplements, (we recommend using SOC-HCS probiotics)

6. water

7. Rice bran or bran

Steps of Making Goat Fermentation Feed: 
1. Chop straw or banana stem by using a chopping tool, this stage serves to make the fermentation process easier.

2. Prepare a place for manufacture, you can use a tarpaulin, large plastic or you can use a large barrel.

3. Dissolve sugar or sugar cane with water plus SOC-HCS probiotic solution.

4. Put the straw, bran and rice bran in the place for manufacture that has been prepared previously.

5. Flush all ingredients that have been arranged evenly in the place for manufacture with a solution of sugar and SOC-HCS that had been dissolved with water.

6. Stir all ingredients until evenly distributed.

7. After everything has been stirred evenly, then close the place for manufacture with a tarp or with anything. Make sure it is airtight. .

8. After everything is closed tightly (airtight) the fermentation process is underway now you just have to wait for 1 - 14 days, then fermented feed made from straw will soon be ready, or if the manufacture of fermented feed using banana stem, it can be faster.

After the fermented feed, you have made is ready, now you can give your livestock (goats) the fermented feed, but it is better if the fermented feed is aerated in advance for about 15 minutes after then you can give the fermented feed to the goat.

The characteristics of the ready-made fermented feed:

1. There is an increase in temperature

2. There is a change in color

3. Become weathered/soft

How to feed the fermented feed to goats:

1. If you are going to feed fermented feed to animals (for example goats), then the fermented straw must be aerated first before being given to animals.

2. As long as the fermented feed is not directly exposed to the sun or not directly exposed to rain, the SOC fermented animal feed can last for years.

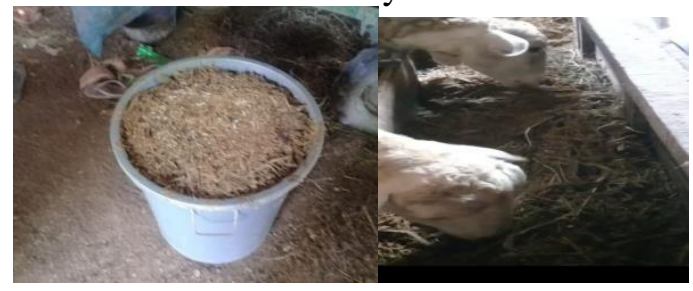

Gambar 2.3.1. Fermented Goat Fodder

\section{RESULT AND DISCUSSION}

This activity was carried out by a combination of counseling, training, hands-on practice and work evaluation. This activity was supported by the village chief and his officials will play a role in helping this implementation by giving permission and contacting the Tanjung Rejo village community group. While the benefits obtained will increase the knowledge of human resources in terms of the utilization of organic waste into goat fodder for the interests of the Tanjung Rejo village community.
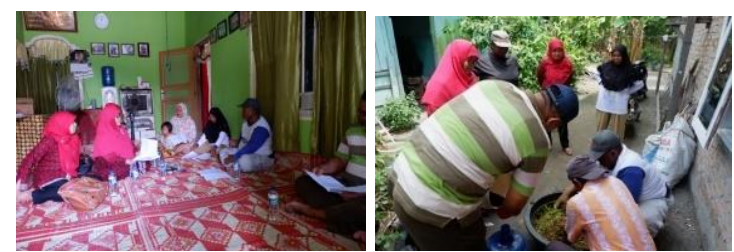

Gambar 3.1. Theory presented by team (left) and practiced by team and community (right).

Organic waste used such as banana stem, straw and others. A fermented straw feed can increase crude protein content by $4.88 \%$ from $4.01 \%$ to $9.09 \%$, and reduce crude fiber by $6.32 \%$ 
from $24.76 \%$ to $18.44 \%$ (Basuni, 2010).The process of paddy straw fermentation was carried out to increase its nutritional value, causing the preference for goats (Syamsu, 2006).

Goat feed mostly consists of forage, grass and foliage. For adult goats, it takes about six $\mathrm{kg}$ of forage/head/day. For normal growth, feed ingredients given to livestock must contain protein, energy, minerals, and vitamins, according to the needs of the animals that eat them (Cullison, 1979). Livestock nutrient needs are influenced by several factors including growth rate, body size, environment, heredity, disease, species, carcass fat amount, ration nutrient balance and its deficiencies (Williamson \& Payne. 1993).Producing livestock that achieves optimal production, the feed provided must be sufficient for the substances needed such as carbohydrates, fats, proteins, vitamins, minerals and water and in accordance with the needs of livestock. Ruminant animal protein and energy requirements depend on several factors including life weight, body weight gain, and feed composition (Soeparno 1994).

The main target of breeders is to provide fermented feed to livestock hence when storing fermented feed that is available in large quantities can last in a long time without reducing the nutrient content in the feed. Hence this is very helpful for goat breeders in providing forage (fiber) during the dry season and is hampered by rain during the rainy season in finding green food for goat.

The benefits of this activity are to increase knowledge (HR) in making fermented feed, one of the most appropriate alternatives to overcome the scarcity and rising feed prices and the environment becomes more sustainable.The community service activities were related to Village Officials such as the Village Chief and his staff, who are very supportive of this activity. Support in licensing and providing a place for counselling and training on the utilization of organic waste into fermented feed in the village of Tanjung Rejo.

The evaluation was carried out by monitoring the village of Tanjung Rejo to find out what obstacles were occurring. Furthermore, the next monitoring was done via telephone to continue to communicate with the Tanjung Rejo village community regarding the utilization of organic waste into fermented goat feed.

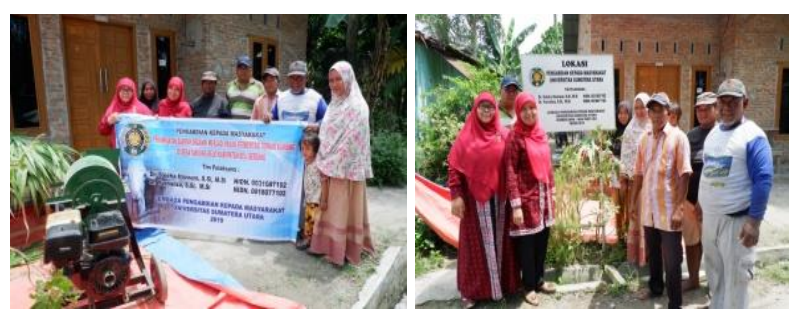

Gambar 3.2. The team who conducted the social engangement from USU and communities at Tanjung Rejo

\section{CONCLUSION}

Based on the community service activities regarding the Utilization of Organic Waste into Fermented Goat Fodder in Tanjung Rejo Village, Deli Serdang Regency, the following conclusions can be drawn:

1. Utilization of organic waste can be converted into fermented goat fodder.

2. Utilization of organic waste can provide economic and ecological value.

3. There is good collaboration between USU and the community in Tanjung Rejo village, Deli Serdang Regency.

\section{ACKNOWLEDGMENTS}

This article can be successfully conducted with the assistance and contribution from many parties. We would like to thank to the Rector of USU for finantial support by Mono Tahun Social Engagement Non PNBP 2019 and all participants who have helped the implementation of this Community Service. 


\section{REFERENCES}

Alim H. 2014. Pertambahan Bobot Kambing Marica Jantan dengan Pemberian Pakan Komplit Pada Taraf Protein Yang Berbeda. Program Studi Produksi Ternak. Universitas Hasanuddin Makasar.

Basuni, R. 2010. Model sistem integrasi padi sapi potong di lahan sawah. Forum Pasca Sarjana, Juli 2010, Vol. 33 : 177- 190

Cullison, A.F. 1979. Feed and Feeding. Reston Publishing Company, Inc. AprenticeHall Company, Reston

Direktorat Jenderal Peternakan dan Kesehatan Hewan (2017). Staistik Peternakan dan Kesehatan Hewan. ISBN : 978-979-628-034-6

Eka M. U . Usman A . Badat M . 2019. Pengaruh Penggunaan Daun Kaliandra Merah (Calliandra calothyrsus) dalam Complete Feed untuk Penggemukan Domba Ekor Gemuk. Jurnal Rekasatwa Peternakan Vol. 1 No. 1, 1 Februari 2019

Parakkasi, A. 1999. Ilmu nutrisi dan makanan ternak ruminan. Penerbit Universitas Indonesia, Jakarta.

Soeparno 1994. Ilmu dan Teknologi Daging. Cetakan 2. Gadjah Mada University Press. Yogyakarta

Syamsu, J.A.2006. Kajian penggunaan starter mikroba dalam fermentasi jerami padi sebagai sumber pakan pada peternakan rakyat di Sulawesi Tenggara. Disampaikan dalam Seminar Nasional Bioteknologi.Puslit Bioteknologi LIPI, Bogor

Wardani, M. 2012. Uji Akurasi Kebuntingan pada Kambing Menggunakan Ultrasonography. Skripsi. Fakultas Peternakan Universitas Brawijaya. Malang

Williamson, G \& W. J. A. Payne. 1993. Pengantar Peternakan di Daerah Tropis. Terjemahan : D. Darmaja. UGM Press, Yogyakarta 